\title{
PENGARUH BUDAYA ORGANISASI DAN KOMPETENSI TERHADAP KINERJA KARYAWAN PADA PT ANGKASA PURA I (PERSERO)
}

\section{THE INFLUENCE OF ORGANIZATIONAL CULTURE AND COMPETENCE ON EMPLOYEE PERFORMANCE IN PT ANGKASA PURA I (PERSERO)}

\author{
Hendri Dunan \\ Universitas Bandar Lampung \\ Email: hendri.dunan@ubl.ac.id \\ Desi Rahmawati \\ Universitas Bandar Lampung \\ Email: desi.16011108@student.ubl.ac.id \\ Appin Purisky Redaputri \\ Universitas Bandar Lampung \\ Email: appin@ubl.ac.id
}

\begin{abstract}
ABSTRAK
Tujuan dari penelitian ini adalah untuk mengetahui pengaruh budaya organisasi dan kompetensi secara parsial dan simultan terhadap kinerja karyawan. Penelitian ini menggunakan jenis penelitian kuantitatif bersifat asosiatif dengan desain penelitian survey deskriptif verifikatif. Metode analisis data yang digunakan adalah analisis regresi berganda. Hasil penelitian ini mendukung semua hipotesis yang diajukan dimana budaya organisasi dan kompetensi memiliki pengaruh positif baik secara parsial maupun simultan terhadap kinerja karyawan. Artinya, budaya organisasi dan kompetensi memiliki peran yang sama penting terhadap peningkatan kinerja karyawan. Untuk meningkatkan kinerja perusahaan, pimpinan harus memperhatikan dan menempatkan karyawan sesuai dengan kemampuan yang dimiliki oleh setiap karyawan, misalnya pimpinan memberi tugas atau tanggungjawab kepada karyawan sesuai dengan keahlian karyawan. Melakukan upaya yang meningkatkan kompetensi dengan cara menambah ilmu pengetahuan serta keterampilan yang dimiliki karyawan yang berhubungan dengan posisi atau jabatan yang dimliki baik melalui pendidikan informal dan nonformal. Melakukan upaya yang meningkatkan budaya organisasi melalui penetapan misi, visi serta arah dan strategi perusahaan yang dapat menumbuhkan sense belonging yang tinggi yang pada akhirnya akan meningkatkan kinerja pegawai.
\end{abstract}

Kata Kunci: budaya organisasi, kompetensi, dan kinerja karyawan. 


\section{ABSTRACT}

The purpose of this study was to determine the effect of organizational culture and competence partially and simultaneously on employee performance. This study used an associative quantitative research design with descriptive verification survey research design. The data analysis method used is multiple regression analysis. The results of this study support all the proposed hypotheses where organizational culture and competence have a positive influence either partially or simultaneously on employee performance. This means that organizational culture and competence have an equally important role in improving employee performance. To improve company performance, leaders must pay attention to and place employees according to the abilities possessed by each employee, for example, the leadership assigns tasks or responsibilities to employees according to the employee's expertise. Make efforts to improve competence by increasing the knowledge and skills possessed by employees associated with positions or positions possessed both through informal and non-formal education. Making efforts to improve the Organizational Culture through the establishment of the company's mission, vision and direction and strategy that can foster a high sense of belonging which in turn will improve employee performance.

Keywords: organization culture, competence, and employee performance.

\section{PENDAHULUAN}

Persaingan yang semakin kompetitif di era globalisasi telah memacu bangsa-bangsa di seluruh dunia untuk meningkatkan kualitas sumber daya manusia, sehingga menuntut perusahaan untuk memiliki karyawan yang mampu bekerja secara produktif, efektif, efisien serta profesional. Karena pada saat ini perusahaan tidak hanya mengejar pencapaian produktivitas yang tinggi saja, tetapi juga memperhatikan kinerja dalam proses pencapaiannya. Dengan demikian kinerja merupakan faktor kunci bagi setiap individu dan perusahaan dalam pencapaian produktivitas. Faktor-faktor dari dalam perusahaan seperti budaya organisasi dan kompetensi yang sesuai dengan kemampuan diindikasikan mampu mempengaruhi kinerja karyawan yang berkualitas dan berhasil dalam mencapai tujuan serta menyelesaikan tugas dan tanggungjawabnya.

Budaya organisasi merupakan salah satu faktor yang mempengaruhi kinerja karyawan. Budaya organisasi melibatkan kebiasan-kebiasaan yang berlaku pada sebuah perusahaan (Sunarso, 2009). Kebiasaan-kebiasaan ini dapat dilihat dari kebiasaan kerja keras atau santai-santai, kekompakan kerja atau kebersamaan, dan kedisiplinan. Kurangnya kerja sama antar karyawan dalam menyelesaikan tugas yang dibebankan oleh pimpinan, kurangnya kesadaran karyawan untuk bersedia melakukan pekerjaaan yang bukan tugasnya demi kelancaran operasional perusahaan, serta kurangnya kesadaran terhadap penyimpanganpenyimpangan yang telah terjadi dalam pelaksanaan tugas pekerjaan juga dapat menimbulkan kemungkinan terjadinya masalah dalam budaya organisasi. Kurangnya pembinaan dan sosialisasi mengenai Budaya yang ada menjadikan Budaya tersebut belum sepenuhnya didukung dan dijalankan oleh karyawan, sehingga hal ini dapat menjadi salah satu faktor penyebab masalah dalam budaya organisasi.

Selain budaya organisasi, kompetensi dari karyawan juga penting untuk diperhatikan agar pekerjaan yang dilakukan oleh karyawan berjalan secara maksimal sehingga tujuan perusahaan dapat tercapai. Kurangnya pemahaman dalam melakukan suatu pekerjaan akan berakibat pada kinerja karyawan di perusahaan, diantaranya adalah kurangnya koordinasi antar bagian yang menyebabkan suatu pekerjaan tidak berjalan secara optimal. Rendahnya Kompetensi dapat dilihat dari pendidikan formal terakhir yang telah ditempuh oleh karyawan. Karyawan yang kompetensinya tidak sesuai antara kualifikasi tingkat pendidikan yang dibutuhkan perusahaan dengan tingkat pendidikan terakhir yang telah ditempuh oleh 
karyawan dapat mengindikasikan adanya masalah dalam kompetensi (Silvia et al, 2016). Perbedaan antara para karyawan dalam hal jenjang pendidikan yang tidak strata, mengindikasikan adanya masalah dalam kualitas sumber daya manusia pada karyawan yang tergolong rendah.

Tujuan penelitian adalah untuk mengetahui, membuktikan dan menganalisis bahwa budaya organisasi dan kompetensi memiliki pengaruh terhadap kinerja karyawan pada PT Angkasa Pura I (Persero) dan mengetahui dan menganalisis variabel yang memiliki dampak paling signifikan terhadap kinerja karyawan pada PT Angkasa Pura I (Persero).

Menurut Nawawi dalam Gaol (2014:44), sumber daya manusia adalah orang yang bekerja dan berfungsi sebagai aset organisasi atau perusahaan yang dapat dihitung jumlahnya serta merupakan potensi yang menjadi penggerak organisasi atau perusahaan. Semua potensi sumber daya manusia berdampak pada upaya organisasi atau perusahaan dalam mencapai tujuan. Menurut Sutrisno (2011), bagaimanapun majunya suatu teknologi, perkembangan informasi, tersedianya modal dan memadainya bahan, jika tanpa sumber daya manusia sulit bagi organisasi atau perusahaan untuk mencapai tujuannya. Sutrisno (2014:3) juga berpendapat bahwa perspektif pokok sumber daya manusia adalah kontribusinya terhadap organisasi atau perusahaan, sedangkan perspektif pokok manusia adalah perlakuan kontribusi terhadapnya yang akan menentukan kualitas dan kapabilitas hidupnya. Sumber daya manusia merupakan sumber daya yang memiliki akal, perasaan, keterampilan, dorongan, keinginan, daya, pengetahuan, dan karya (rasa, karsa dan rasio).

Menurut Marwansyah, (2010:3), manajemen sumber daya manusia dapat diartikan sebagai pendayagunaan sumber daya manusia di dalam organisasi atau perusahaan, yang dilakukan melalui fungsi-fungsi perencanaan sumber daya manusia, rekrutmen dan seleksi, pengembangan sumber daya manusia, perencanaan dan pengembangan karir, pemberian kompensasi dan kesejahteraan, keselamatan dan kesehatan kerja, dan hubungan industrial. Menurut Sulistiyani dan Rosidah (2009:11), manajemen sumber daya manusia merupakan potensi berupa aset dan berfungsi sebagai modal dalam organisasi bisnis yang dapat diwujudkan menjadi potensi nyata secara fisik dan non fisik dalam mewujudkan eksistensi organisasi atau perusahaan. Manajemen sumber daya manusia merupakan aktivitas-aktivitas yang dilaksanakan agar sumber daya manusia di dalam organisasi digunakan secara efektif guna mencapai berbagai tujuan. Tujuan utama manajemen sumber daya manusia adalah untuk meningkatkan kontribusi pegawai terhadap organisasi dalam rangka mencapai produktivitas organisasi yang bersangkutan.

Menurut Mas'ud (2004) budaya organisasi adalah sistem makna, nilai-nilai dan kepercayaan yang dianut bersama dalam suatu organisasi atau perusahaan yang menjadi petujuk untuk bertindak dan membedakan organisasi atau perusahaan yang satu dengan organisasi atau perusahaan yang lain. Budaya organisasi selanjutnya menjadi karakteristik khas atau identitas utama organisasi atau perusahaan yang perlu dijaga dan dipertahankan. Budaya organisasi pada dasarnya akan mewakili norma-norma perilaku yang diikuti oleh para anggota organisasi atau perusahaan, termasuk mereka yang berada dalam hirarki organisasi atau perusahaan. Budaya organisasi dapat digambarkan sebagai nilai, norma dan artefak yang diterima oleh anggota organisasi atau perusahaan sebagai iklim organisasi yang akan mempengaruhi dan dipengaruhi strategi organisasi, struktur dan sistem organisasi.

Menurut Darsono dan Siswandoko (2011:123) kompetensi adalah perpaduan antara keterampilan, pengetahuan, kreativitas dan sikap positif terhadap pekerjaan tertentu yang diwujudkan dalam suatu kinerja. Kompetensi merupakan karakter seorang pekerja yang mampu menghasilkan kinerja yang lebih baik dibandingkan orang lain. Kompetensi terdiri dari beberapa jenis karakteristik berbeda yang mendorong perilaku. Pondasi karakteristik ini terbukti dalam cara seseorang berperilaku ditempat kerja. Kompetensi adalah mengenai orang seperti apa dan apa yang dapat mereka lakukan. Kompetensi ditemukan pada orang- 
orang yang diklasifikasikan memiliki kinerja unggul atau efektif. Kompetensi terdiri dari beberapa jenis karakteristik berbeda yang mendorong perilaku. Pondasi karakteristik ini terbukti dalam cara seseorang berperilaku ditempat kerja. Palan, (2007:6) mengatakan bahwa kompetensi adalah mengenai orang seperti apa dan apa yang dapat mereka lakukan. Kompetensi ditemukan pada orang-orang yang diklasifikasikan memiliki kinerja unggul atau efektif. Kompetensi sebagai karakteristik yang mendasari seseorang dan berkaitan dengan efektifitas kinerja individu dalam pekerjaannya.

Menurut Yusniar Lubis, Bambang Hermanto \& Emron Edison (2018) "kinerja adalah hasil dari suatu proses yang mengacu dan diukur selama periode waktu tertentu berdasarkan ketentuan, standar atau kesepakatan yang telah ditetapkan sebelumnya. Kinerja karyawan merupakan hasil atau tingkat keberhasilan seseorang secara keseluruhan selama periode tertentu didalam melaksanakan tugas dibandingkan dengan hasil kemungkinan, seperti standar kerja, target atau sasaran atau kriteria yang ditentukan terlebih dahulu dan disepakati bersama. Menurut Vroom dalam Handayani (2001), tingkat sampai sejauh mana keberhasilan seseorang dalam menyelesaikan tugas pekerjaannya disebut sebagai "level of performance". Porter \& Lawler dalam Handayani (2001) menyatakan bahwa "succesfull role achievement" yang diperoleh seseorang akan berasal dari perbuatannya. Dengan kata lain, kinerja karyawan merupakan suatu bentuk kesuksesan seseorang untuk mencapai peran atau terget tertentu yang berasal dari perbuatannya sendiri. Kinerja seseorang dikatakan baik apabila hasil kerja individu tersebut dapat melampaui peran atau target yang ditentukan sebelumnya.

\section{METODE PENELITIAN}

Jenis penelitian yang digunakan adalah penelitian kuantitatif bersifat asosiatif. Menurut Sugiyono (2007:13) penelitian kuantitatif bersifat asosiati diartikan sebagai metode penelitian yang digunakan untuk meneliti populasi atau sampel pada umumnya dilakukan secara random, pengumpulan data menggunakan instrumen penelitian, analisis data bersifat kuantitatif atau statistik dengan tujuan untuk menguji hipotesis yang telah ditetapkan.

Desain penelitian ini merupakan penelitian survey deskriptif verifikatif, Menurut Patra, (2013:26) penelitian survey deskriptif verifikatif yaitu penelitian yang memberikan gambaran yang sebenarnya atas kondisi objek penelitian berdasarkan data-data yang diperoleh. Basrowi dan Kustoro (2006:96) mengatakan penelitian diskriptif adalah penelitian yang bertujuan untuk mengeksplorasi, mengklarifikasi, dan menggambarkan keadaan objek atau subjek penelitian secara sistematis, faktual dan akurat mengenai suatu fenomena atau kenyataan sosial, fakta-fakta, sifat-sifat serta hubungan antar fenomena yang diselidiki dengan cara mendeskripsikan jumlah variabel yang berkenaan dengan masalah dan unit yang diteliti. Sedangkan verifikatif menunjukkan penelitian mencari pengaruh antara variabel bebas terhadap variabel terikat.

Sejalan dengan Habiburrahman, dkk. (2019:42), penelitian dilakukan dengan pendekatan Library Research / pustaka dan Field Research / penelitian lapangan. Pada pendekatan pustaka akan dikaji bahan literatur terkait teori tentang pengaruh budaya organisasi dan kompetensi terhadap kinerja karyawan, sementara penelitian lapangan dilakukan dengan cara pengumpulan data melalui observasi dengan penyebaran kuisioner.

Patra (2013:28) mengatakan populasi merupakan objek atau subyek yang berbeda dalam suatu wilayah dan memenuhi syarat-syarat tertentu dan memiliki kaitan masalah penelitian. Populasi dari penelitian ini adalah karyawan yang bekerja di PT Angkasa Pura I (Persero) sebanyak karyawan 3209 orang. Sedangkan sampel menurut Sugiyono (2009: 81) adalah bagian dari jumlah dan karakteristik yang dimiliki oleh populasi tersebut. Bila populasi besar, dan peneliti tidak mungkin mempelajari semua yang ada pada populasi, misalnya karena keterbatasan dana, tenaga dan waktu, maka peneliti dapat menggunakan sampel yang diambil dari populasi itu. Pengambilan sampel ini sesuai dengan pendapat 
Habiburrahman, dkk. (2018:30) yaitu menggunakan pendapat Slovin dengan asumsi populasi berdistribusi normal dan tingkat kesalahan pengambilan sampel atas populasi sebesar $10 \%$. Bila populasi besar maka besarnya sampel minimal sebesar 100 responden. Adapun rumus yang digunakan yaitu sebagai berikut:

$$
n=\frac{N}{1+N e^{2}}=\frac{3209}{1+3209(0,1)^{2}}=96,977 \text { yang jika dibulatkan menjadi } 97 \text { responden. }
$$

Adapun alat yang digunakan dalam penelitian ini adalah uji validitas yang digunakan untuk mengukur sah atau valid tidaknya suatu kuesioner. Berdasarkan hasil uji validitas variabel budaya organisasi yang mempunyai 12 item pernyataan, variabel kompetensi yang memiliki 10 item pernyataan, dan kinerja karyawan yang memiliki 10 item pernyataan dengan dengan nilai signifikansi lebih kecil dari 0,05 serta $r_{\text {hitung }}$ lebih besar daripada $r_{\text {tabel, }}$ maka item pernyaatan dalam kuisioner ini dianggap valid.

Penelitian ini menggunakan uji reliabilitas yang digunakan untuk mengukur suatu kuesioner yang merupakan indikator dari variabel atau konstruk. Berdasarkan hasil uji reabilitas semua variabel, menunjukan nilai Cronbach's alpha variabel budaya organisasi sebesar 0,852, kompetensi sebesar 0,902 dan kinerja karyawan sebesar 0,831. Hal ini menunjukan bahwa pernyataan dalam kuesioner ini reliable karena nilai Cronbach Alpha lebih besar dari 0,6. Dengan demikian, dapat disimpulkan bahwa setiap item pernyataan yang digunakan mampu memperoleh data yang konsisten.

Kemudian, penelitian ini menggunakan uji Statistik deskriptif yang memberikan gambaran suatu data yang dilihat dari nilai minimum, maksimum, rata-rata, dan standar deviasi. Juga, Analisis regresi yang merupakan metode analisis untuk penelitian melibatkan satu variabel terikat yang diperkirakan berhubungan dengan satu atau lebih variabel bebas. Pengujian hipotesis juga dilakukan dengan menggunakan pengujian secara parsial atau Uji $\mathrm{T}$, dan pengujian secara simultan atau Uji $\mathrm{F}$ dengan menggunakan tingkat kepercayaan 95\% atau $(\alpha=0,05)$, dan Koefisien determinasi (R2) yang digunakan untuk mengukur seberapa jauh kemampuan model dalam menerangkan variasi variabel dependen (kinerja karyawan).

\section{HASIL DAN PEMBAHASAN}

Responden dalam penelitian ini adalah karyawan PT Angkasa Pura I (Persero) yang berjumlah 97 orang. Berdasarkan demografi responden yang meliputi usia, jenis kelamin, masa kerja dan tingkat pendidikan, dapat digambarkan bahwa jawaban-jawaban dari responden yang paling dominan adalah jawaban dari karyawan yang berusia antara 21-30 tahun dengan jenis kelamin laki-laki dan memiliki pendidikan terakhir S1 serta lama bekerja karyawan pada rentang antara 1-5 tahun. Dalam penelitian ini, peneliti melakukan analisis data dengan hasil sebagai berikut :

\section{Analisis Deskriptif}

Tabel 1. Analisis Deskriptif

\section{Descriptive Statistics}

\begin{tabular}{|c|c|c|c|c|c|}
\hline & N & Minimum & Maximum & Mean & Std. Deviation \\
\hline Budaya Organisasi & 97 & 34,00 & 60,00 & 47,5258 & 6,34444 \\
Kompetensi & 97 & 32,00 & 50,00 & 42,4124 & 4,35352 \\
Kinerja Karyawan & 97 & 31,00 & 50,00 & 42,0619 & 4,28859 \\
Valid N (listwise) & 97 & & & & \\
\hline
\end{tabular}

Sumber : hasil olahan penulis (2020) dengan bantuan software SPSS 
Tabel diatas menjelaskan bahwa pada variabel budaya organisasi memiliki jawaban minimum responden yang didapat dari penyebaran kuesioner sebesar 34 dan jawaban maksimum responden yang di dapat dari penyebaran kuesioner adalah sebesar 60, dengan rata-rata total jawaban 47,52 dengan standar deviasi sebesr 6,344. Variabel kompetensi memiliki jawaban minimum sebesar 32 dan jawaban maksimum sebesar 50, dengan nilai rata-rata total jawaban reponden sebesar 42,41 dan standar deviasi sebesar 4,353. Sedangkan, variabel kinerja karyawan memiliki jawaban minimum sebesar 31, dan jawaban maksimum sebesar 50 dengan nilai rata-rata sebesar 42,06 dan standar deviasi sebesar 4,288 .

\section{Analisis Regresi Linier Berganda}

Tabel 2. Analisis Regresi Linier Berganda

Coefficients $^{\mathrm{a}}$

\begin{tabular}{|ll|r|r|r|r|r|}
\hline \multirow{2}{*}{ Model } & \multicolumn{2}{|c|}{$\begin{array}{c}\text { Unstandardized } \\
\text { Coefficients }\end{array}$} & $\begin{array}{c}\text { Standardized } \\
\text { Coefficients }\end{array}$ & & \multirow{2}{*}{ Sig. } \\
\cline { 2 - 4 } & \multicolumn{1}{|c|}{ B } & Std. Error & \multicolumn{1}{c|}{ Beta } & \multicolumn{1}{c|}{ T } & \multicolumn{1}{c|}{ Sig } \\
\hline 1 & (Constant) & 5,526 & 2,729 & & 2,025 &, 046 \\
& X1 &, 173 &, 044 &, 256 & 3,919 &, 000 \\
X2 &, 668 &, 064 &, 678 & 10,376 &, 000 \\
\hline
\end{tabular}

Sumber : hasil olahan penulis (2020) dengan bantuan software SPSS

Hasil perhitungan pada tabel diatas dimasukkan dalam rumus sebagai berikut:

$$
Y=a+b_{1} X_{1}+b_{2} X_{2}+e t
$$

Dengan perolehan nilai konstanta (a) sebesar 5,526 , nilai $b_{1}$ sebesar 0,173 dan nilai $b_{2}$ sebesar 0,668 maka persamaan regresi linier berganda menjadi sebagai berikut:

$$
Y=5,526+0,173 X_{1}+0,668 X_{2}+\text { et }
$$

Dimana, nilai konstanta sebesar 5,526 mengandung arti kinerja karyawan akan tetap atau konstan sebesar 5,526 tanpa adanya budaya organisasi dan kompetensi. Nilai koefisien regresi $X_{1}$ bertanda positif sebesar 0,173 , artinya pengaruh budaya organisasi terhadap kinerja karyawan sebesar 0,173, atau apabila budaya organisasi meningkat sebesar 1 point dengan asumsi kompetensi dianggap konstan, maka diprediksikan kinerja karyawan akan meningkat sebesar 0,173 point. Nilai koefisien regresi $X_{2}$ bertanda positif sebesar 0,668 , artinya pengaruh kompetensi terhadap kinerja karyawan sebesar 0,668 , atau apabila kompetensi meningkat sebesar 1 point dengan asumsi variabel budaya organisasi dianggap konstan, maka diprediksikan kinerja karyawan akan meningkat sebesar 0,668 point. Dan nilai koefisien regresi $X_{2}$ lebih besar dari koefisien regresi $X_{1}$, artinya kompetensi memiliki pengaruh paling dominan dibandingkan dengan budaya organisasi dalam hal meningkatkan kinerja karyawan dikarnakan kompetensi memberikan sumbangan nilai 0,668 terhadap peningkatan karyawan sedangkan budaya organisasi sebesar 0,173. 


\section{Pengujian Hipotesis \\ Uji T (Parsial)}

Tabel 3. Uji T (Uji Parsial)

Coefficients $^{\mathrm{a}}$

\begin{tabular}{|c|c|c|c|c|c|}
\hline \multirow[t]{2}{*}{ Model } & \multicolumn{2}{|c|}{$\begin{array}{c}\text { Unstandardized } \\
\text { Coefficients }\end{array}$} & $\begin{array}{c}\text { Standardized } \\
\text { Coefficients }\end{array}$ & & \\
\hline & B & Std. Error & Beta & $\mathrm{T}$ & Sig. \\
\hline 1 (Constant) & 5,526 & 2,729 & & 2,025 & ,046 \\
\hline $\mathrm{X} 1$ & 173 & ,044 & ,256 & 3,919 & ,000 \\
\hline$X 2$ & 668 &, 064 & ,678 & 10,376 &, 000 \\
\hline
\end{tabular}

Sumber : hasil olahan penulis (2020) dengan bantuan software SPSS

Berdasarkan tabel diatas dapat dijelaskan bahwa pengaruh secara parsial pada variabel Budaya Organisasi (X1) memperoleh $t_{\text {hitung }}$ sebesar 3,919 dan tingkat signifikan sebesar 0,000. Sedangkan nilai tabel pada df : $n-k-1$ atau $(97-2-1)=94$ sebesar 1,661 dengan nilai signifikan $a=0,05$. Karena nilai thitung $(3,919)>t_{\text {tabel }}(1,661)$ dan tingkat signifikansi 0,000 < 0,05, maka Ha diterima dan Ho ditolak, artinya variabel Budaya Organisasi (X1) berpengaruh positif dan signifikan terhadap Kinerja Karyawan ( $Y$ ). Kemudian pengaruh secara parsial pada variabel Kompetensi (X2) memperoleh $t_{\text {hitung }}$ sebesar 10,376 dan tingkat signifikan sebesar 0,000. Sementara nilai $t_{\text {tabel }}$ pada df : $n-k-1$ atau $(97-2-$ $1)=94$ sebesar 1,661 dengan nilai signifikan $a=0,05$. Karena nilai $t_{\text {hitung }}(10,376)>t_{\text {tabel }}$ $(1,661)$ dan tingkat signifikan 0,000 $<0,05$, maka Ha diterima dan Ho ditolak, artinya variabel Kompetensi (X2) berpengaruh positif dan signifikan terhadap Kinerja Karyawan (Y).

\section{Uji F (Simultan)}

\begin{tabular}{|c|c|c|c|c|c|}
\hline Model & $\begin{array}{l}\text { Sum of } \\
\text { Squares }\end{array}$ & Df & Mean Square & $\mathrm{F}$ & Sig. \\
\hline $\begin{array}{ll}1 & \text { Regression } \\
& \text { Residual } \\
\text { Total }\end{array}$ & $\begin{array}{r}1165,374 \\
600,255 \\
1765,629\end{array}$ & $\begin{array}{r}2 \\
94 \\
96\end{array}$ & $\begin{array}{r}582,687 \\
6,386\end{array}$ & 91,249 &, $000^{\mathrm{a}}$ \\
\hline
\end{tabular}

Sumber : hasil olahan penulis (2019) dengan bantuan software SPSS

Berdasarkan tabel hasil uji $F$, diperoleh $f_{\text {hitung }}$ sebesar 91,249 dan tingkat signifikan sebesar 0,000 . Sedangkan nilai $f_{\text {tabel }}$ pada $d f=k ; n-k$ atau $(2 ;(97-2)=95)$ sebesar 3,09 dengan nilai signifikan $a=0,05$. Karena nilai $f_{\text {hitung }}(91,249)>f_{\text {tabel }}(3,09)$ dan tingkat signifikansi $0,000<0,05$, maka Ha diterima dan Ho ditolak, sehingga dapat dikatakan bahwa variabel budaya organisasi dan kompetensi secara bersama-sama (simultan) berpengaruh secara signifikan terhadap variabel kinerja karyawan.

\section{Koefisien Determinasi}

Tabel 5. Uji Koefisien Determinasi

Model Summary

\begin{tabular}{|l|r|r|r|r|}
\hline Model & $\mathrm{R}$ & R Square & $\begin{array}{c}\text { Adjusted R } \\
\text { Square }\end{array}$ & $\begin{array}{c}\text { Std. Error of } \\
\text { the Estimate }\end{array}$ \\
\hline 1 &, $812^{\mathrm{a}}$ &, 660 &, 653 & 2,52699 \\
\hline
\end{tabular}

Sumber : hasil olahan penulis (2019) dengan bantuan software SPSS 
Berdasarkan tabel 4.9, diperoleh koefisien determinasi (R2) sebesar 0,653 atau 65\%. Maka dapat disimpulkan bahwa $66 \%$ variabel kinerja karyawan dapat dijelaskan oleh variabel budaya organisasi dan kompetensi. Sedangkan 0,347 atau 35\% lainnya dipengaruhi dan dijelaskan oleh variabel lain yang tidak masuk dalam penelitian ini.

\section{Pembahasan}

Berdasarkan hasil analisis data, dapat disimpulkan bahwa budaya organisasi dan kompetensi berpengaruh terhadap kinerja karyawan pada PT Angkasa Pura I (Persero). Hal ini mengandung arti bahwa semakin tinggi budaya organisasi dan kompetensi maka akan mampu meningkatkan kinerja karyawan itu sendiri.

Dalam penelitian ini, budaya organisasi berpengaruh signifikan terhadap kinerja karyawan yang ditunjukkan dengan nilai $t_{\text {hitung }}(3,919)$ lebih besar dari nilai $t_{\text {tabel }}(1,661)$, sedangkan hasil signifikansi yang diperoleh sebesar 0,000 lebih kecil daripada a yang ditentukan yaitu 0,05 sehingga dapat dikatakan signifikan. Dengan demikian, Ho ditolak $\mathrm{Ha}$ diterima, atau dapat dikatakan bahwa budaya organisasi berpengaruh positif dan signifikan terhadap kinerja karyawan pada PT Angkasa Pura I (Persero). Hasil penelitian ini sejalan dengan penelitian yang dilakukan oleh Sulbahri Madjir dan Listeti Yuniar (2013) bahwa ada pengaruh Budaya Organisasi secara signifikan terhadap Kinerja Pegawai Bank Sumsel Babel Cabang Syariah Palembang. Dimana nilai t hitung variabel Budaya Organisasi adalah 3.138 $>$ nilai t tabel yaitu sebesar 2.056 yang berarti variabel budaya organisasi mempunyai pengaruh yang signifikan secara parsial terhadap variabel kinerja. Sementara nilai sig t 0,04 yang berarti < nilai a yaitu 0,05 (5\%). Berdasarkan uraian diatas, dapat disimpulkan bahwa semakin tinggi budaya organisasi, maka akan semakin baik kinerja karyawan, sebaliknya semakin rendah budaya organisasi maka semakin buruk kinerja karyawan.

Dalam penelitian ini, kompetensi memiliki pengaruh paling dominan dibandingkan dengan budaya organisasi dalam hal meningkatkan kinerja karyawan. Kompetensi memberikan sumbangan nilai 0,668 terhadap peningkatan karyawan sedangkan budaya organisasi sebesar 0,173 . Hasil penelitian ini sejalan dengan penelitian yang dilakukan Yussi Rapareni (2013) dimana berdasarkan pengujian yang telah dilakukan, ternyata yang lebih berpengaruh terhadap kinerja karyawan adalah Kompetensi komunikasi dari pada kecerdasan emosional dan budaya organisasi dengan peningkatan sebesar 72,7\%. Berdasarkan uraian diatas dapat disimpulkan bahwa Semakin kuat Kompetensi komunikasi pada karyawan, maka akan memberikan pengaruh yang positif terhadap Kinerja Karyawan. Hal ini menunjukkan bahwa peningkatan Kinerja Karyawan sangat dipengaruhi oleh kompetensi sehingga dapat digunakan sebagai salah satu syarat yang harus dimiliki seorang karyawan dalam menempati satu posisi atau jabatan tertentu, karena jika tidak maka akan menambah beban perusahaan. Pada akhirnya kompetensi diharapkan dapat meningkatkan produktifitas dan memacu kinerja.

Dalam hasil penelitian ini juga budaya organisasi dan kompetensi secara bersamasama memiliki pengaruh positif dan signifikan terhadap kinerja karyawan yang ditunjukkan dengan nilai $f_{\text {hitung }}(91,249)$ lebih besar dari nilai $f_{\text {tabel }}(3,09)$, sedangkan hasil signifikansi yang diperoleh sebesar 0,000 lebih kecil daripada a yang ditentukan yaitu 0,05 sehingga dapat dikatakan signifikan. Dengan demikian, Ho ditolak Ha diterima, atau dapat dikatakan bahwa budaya organisasi dan kompetensi secara bersama-sama memiliki pengaruh positif dan signifikan terhadap kinerja karyawan pada PT Angkasa Pura I (Persero).

Hasil penelitian ini sejalan dengan penelitian yang dilakukan oleh Pristiyanilicia Putri (2018) dimana variabel kepemimpinan, kompetensi dan budaya organisasi berpengaruh positif dan signifikan secara simultan terhadap kinerja dosen STMIK/AMIK Royal Kisaran. Kontribusi pengaruh kepemimpinan, kompetensi dan budaya organisasi terhadap kinerja dosen sebesar $54,6 \%$ sedangkan sisanya $45,4 \%$ dipengaruhi oleh variabel lainnya yang 
tidak masuk dalam penelitian. Berdasarkan uraian diatas, dapat disimpulkan bahwa semakin tinggi kontribusi budaya organisasi dan kompetensi, maka akan semakin baik kinerja karyawan, sebaliknya semakin rendah kontribusi budaya organisasi dan kompetensi, maka semakin buruk kinerja karyawan.

\section{KESIMPULAN}

Penelitian ini dilakukan dengan tujuan untuk menguji pengaruh budaya organisasi dan kompetensi terhadap kinerja karyawan pada PT Angkasa Pura I (Persero). Berdasarkan hipotesis yang diajukan serta hasil yang diperoleh atas analisis yang telah dilakukan peneliti sebelumnya, maka dapat disimpulkan bahwa:

1) Budaya Organisasi berpengaruh positif terhadap Kinerja Karyawan.

2) Kompetensi berpengaruh positif terhadap Kinerja Karyawan.

3) Budaya Organisasi dan Kompetensi secara bersama-sama berpengaruh positif dan signifikan terhadap Kinerja Karyawan.

Berdasarkan hasil penelitian, saran-saran yang dapat peneliti sampaikan adalah:

\section{Bagi Perusahaan}

Penelitian ini diharapkan dapat menjadi manfaat bagi PT. Angkasa Pura I (Persero) sebagai bahan pertimbangan agar lebih memperhatikan kebutuhan karyawan terutama dalam hal budaya organisasi, kompetensi dan kinerja karyawan. Berdasarkan hasil penelitian, peneliti menyarankan:

1. Untuk meningkatkan kinerja perusahaan, pimpinan harus memperhatikan dan menempatkan karyawan sesuai dengan kemampuan yang dimiliki oleh setiap karyawan, misalnya pimpinan memberi tugas atau tanggungjawab kepada karyawan sesuai dengan keahlian karyawan.

2. Melakukan upaya yang meningkatkan kompetensi dengan cara menambah ilmu pengetahuan serta keterampilan yang dimiliki karyawan yang berhubungan dengan posisi atau jabatan yang dimliki baik melalui pendidikan informal dan nonformal.

3. Melakukan upaya yang meningkatkan Budaya Organisasi melalui penetapan misi, visi serta arah dan strategi perusahaan yang dapat menumbuhkan sense belonging yang tinggi yang pada akhirnya akan meningkatkan kinerja pegawai.

\section{Bagi Peneliti Selanjutnya}

Peneliti selanjutnya yang tertarik untuk mengkaji tema yang serupa yaitu tentang budaya organisasi dan kompetensi serta kinerja karyawan diharapkan untuk mengembangkan penelitian ini, yaitu dengan:

1. Memperluas populasi dan sampel penelitian yang digunakan.

Dengan semakin banyaknya jumlah populasi dan sampel yang digunakan, maka dapat dilihat kinerja suatu organisasi secara lebih objektif dan menyeluruh.

2. Memperbanyak jumlah responden dengan meningkatkan taraf signifikansi responden jika menggunakan rumus slovin dalam menentukan sampel.

3. Menguji bersama dengan variable lain yang diduga kuat dapat mempengaruhi kinerja karyawan seperti kepemimpinan, iklim organisasi, motivasi, kompensasi, budaya kerja dan disiplin kerja.

\section{DAFTAR PUSTAKA}

Basrowi dan Kustoro, Budi. (2006). Metodologi Penelitian. Bandar Lampung: Universitas Lampung. 
Darsono dan Tjatjuk Siswandoko. (2011). Sumber Daya Manusia Abad 21. Jakarta: Nusantara Consulting.

Gaol, CHR. Jimmy L. (2014) "A to Z Human Capital (Manajemen Sumber Daya Manusia) Konsep, Teori, Dan Pengembangan Dalam Konteks Organisasi Public dan Bisnis". Jakarta: PT. Gramedia Widiasarana.

Habiburrahman., Iskandar., Dunan, Hendri., Haninun. (2019). Usaha Mikro Kecil dan Menengah (Model Strategi Pemberdayaan dan Pengembangan). Bandar Lampung: Pusaka Media.

Handayani, Sri. (2001). Pengaruh Komputer Mikro Terhadap Kinerja dan Kepuasan Akuntan Publik. Yogyakarta: Tesis S2 UGM.

Marwansyah. 2010. Manajemen Sumber Daya Manusia. Bandung: Alfabeta.

Mas`ud, Fuad. (2004). Survei Diagnosis Organisasi: Konsep dan Aplikasi. Semarang: Universitas Diponegoro.

Palan. (2007). Competency Management, Teknik Mengimplementasikan Manajemen SDM Berbasis Kompetensi Untuk Meningkatkan Daya Saing Organisasi. Cetakan Pertama, Edisi Bahasa Indonesia, Jakarta: PPM Anggota IKAP.

Kencana, Patra Surya. (2013). Pengaruh Kompetensi Komunikasi dan Kecerdasan Emosional Terhadap Kinerja Karyawan. Lampung : Manajemen Universitas Bandar Lampung.

Lubis, Y., Hermanto, B., \& Edison, E. (2018). Manajemen dan Riset Sumber Daya Manusia. Bandung: Alfabeta

Silvia, et al. (2016). Pengaruh Kompetensi dan Budaya Kerja Terhadap Kinerja Karyawan. ejournal Bisma Universitas Pendidikan Ganesha Jurusan Manajemen. Vol 4 h:1-10. 2016

Sugiyono. (2007). Metode Penelitian Kuantitatif, Kualitatif dan R\&D. Bandung: Alfabeta.

----------. (2009). Metode Penelitian Kuantitatif, Kualitatif dan R\&D. Bandung: Alfabeta.

Sulistiyani dan Rosidah. (2009). Manajemen Sumber Daya Manusia. Yogyakarta : Graha Ilmu.

Sunarso (2009). Dampak Budaya Organisasi Terhadap Kepuasa Kerja. Jurnal Ekonomi dan Kewirausahaan. Vol. 9, No. 1, Hal. $75-85$

Sutrisno, Edy. (2011). Manajemen Sumber Daya Manusia. Jakarta: Kencana. (2014). Manajemen Sumber Daya Manusia. Jakarta: Kencana 